\title{
Potential of International EMail Projects in the Process of Teaching a Foreign Language in Secondary School
}

\author{
Larisa Shapovalova, Southern Federal University, Russia \\ Natalija Koljada, Southern Federal University, Russia* \\ Ekaterina Petrova, Southern Federal University, Russia \\ Julija Gorgennikova, Southern Federal University, Russia
}

\begin{abstract}
The purposes of the article are to identify the theoretical foundations of the implementation of e-mail projects in the process of teaching foreign languages, to analyze the results of implemented e-mail projects, to encourage the implementation of similar projects in order to create conditions for intercultural interaction of students, and to determine the role of partner teachers organizing international e-mail projects. Statistical processing and visualization of data was carried out using the automatic calculation of the student's t-test and the Microsoft Office 2019 package. The survey was conducted among 85 secondary school students aged 12 to 15 years who study German as a second foreign language: 25 coordinators of international e-mail projects - teachers of German, undergraduates, and students of the Department of German Philology of the Institute of Philology, Journalism, and Intercultural Communication of the Southern Federal University. The conducted testing revealed positive aspects of the introduction of international e-mail projects in the process of teaching.
\end{abstract}

\section{KEYWORDS}

Distance Learning, E-Mail, International E-Mail Project, Project Method

\section{INTRODUCTION}

The introduction of information and communication technologies (ICT) in education is a necessary step in the development of a modern information society (Berndt, 2020; Chen et al., 2018; Jeong et al., 2019; Shodmonov, 2020). Today, especially in the context of a pandemic, distance learning is considered one of the most significant and popular forms of education. Distance learning is a format of the educational process in which the learning process is carried out thanks to modern information technologies such as the Internet, e-mail and other types of communication (Gorovenko, 2018; Kyzy et al., 2018). An E-Mail project is understood as the joint work of two or more partners on a project, which is aimed at solving the task in a certain period (Lewis \& Peters, 2017).

The use of ICT in the process of teaching foreign languages, e-mail, in particular, creates new prospects for optimizing the educational process (Balkan, 2020; Rudeau, 2021; Ruthner, 2019). When 
teaching a foreign language, this means that in addition to linguistic and country-specific knowledge, communication skills acquire special value (Horno, 2018). The relevance of using the educational capabilities of the Internet, including e-mail, is beyond doubt, as it enriches the content of the educational process and promotes the use of new modern technologies in teaching foreign languages.

Digital technologies can intensify classes conducted offline and online, and, most importantly, are an effective means of learning during a pandemic (Klieme, 2020; Köller et al., 2020).

E-mail is a technology that is gaining popularity in teaching foreign languages. The importance of writing as a form of communication has changed significantly over the course of history and, above all, over the past decades. Communication by e-mail remains an actual way of communication along with other genres of Internet communication (electronic forums, various chats, video conferences, etc.). E-mail correspondence is a special communicative genre with a number of specific features that distinguish it from other related genres: a special type of interactivity, seriality, temporal deixis, punctuation features. E-mail can be considered as a process of generating written speech, in particular, spontaneous (Zaliznyak \& Mikaelyan, 2006).

E-mail is an effective tool for creating an exciting, productive and real-life communication process, which is quite difficult to achieve in a school classroom or university classroom. Researchers note the positive aspects of using e-mail in the classroom: creating a situation of authentic interaction, increasing motivation to learn a foreign language; productive assimilation of educational material (Ilic, 2018).

Based on the relevance and novelty of the topic, the purpose of this study is to identify the theoretical foundations of the use of E-Mail projects in foreign language classes, substantiate the educational capabilities of an E-Mail project in the process of teaching foreign languages, develop and implement international E-Mail projects in German lessons in secondary school.

The implementation of this goal involves solving the following tasks:

* to study the practical experience of using E-mail projects in foreign language classes in the European educational space;

* identify the components of the E-Mail project: project objectives; project preparation and implementation plan; actions (of students and teachers); project results;

* to identify the factors that have a positive and negative impact on the process of learning foreign languages in the process of implementing an E-Mail project;

* determine the role of the teacher in the preparation and implementation of the E-Mail project;

* develop recommendations for the implementation of research results in the process of teaching foreign languages.

\section{LITERATURE REVIEW}

The researchers emphasize that e-mail correspondence is especially relevant for students with an average and low level of language proficiency, since correspondence contributes to the development of their writing skills, first of all, the consolidation of vocabulary and grammatical structures in the process of writing letters (Claussen \& Pavlovska-Balcerska, 2018; Pavlovska, 2014a, 2014b).

By contacting correspondence partners, students had the opportunity to work with authentic texts that were created by native speakers. In a traditional foreign language lesson, which mainly uses texts from a textbook, the teacher is the dominant partner. The basis for written and oral communication are texts from the textbook, which do not motivate students as much as working with authentic emails (Arranz, 2020).

The experience of organizing and implementing an E-mail project with an American school, presented by Mann and Burgemeister (2018), is interesting and useful. The authors describe in detail all the stages of the project between students of the gymnasium Sarolinum Bernburg (Germany) and students of Laguna Hill HighScool (USA). The researchers draw attention to a number of problems and difficulties in organizing the project, including a rather long search for correspondence partners, 
error correction, different vacation dates in Germany and the USA. The successful implementation of the project is evidenced by the letters of students, photos that are attached to this project. Feedback from students, both positive and negative, is of great importance for the implementation of further projects (Mann \& Burgemeister, 2018).

Domestic researchers emphasize the importance of using E-Mail projects in teaching foreign languages. Scientists have developed methodological recommendations for the implementation of E-Mail projects (Afanasyeva, 2018; Angelova \& Dadoyan, 2015; Makkoveeva, 2016; Tarasov, 2015).

In the process of project implementation, it is mandatory to maintain individual portfolios and project portfolios, which will allow, upon completion of the project, to objectively assess the participation of each participant in the project, the importance of the project for each participant. The success of such projects depends on careful planning, interesting selection of topics, matching the level of learning and the age of students (Angelova \& Dadoyan, 2015).

Implementing an innovative technology for teaching foreign-language productive written speech to elementary school students, the researcher uses the resources of the Internet, includes students in real situations of written communication. The result of such activity is the final communicative product. The author stimulates the internal motivation of students by creating communicative situations (the method of mini-projects), namely, the emergence of the need for students to be active when receiving a letter from a correspondence partner. In the educational process, facilitative learning technologies are actively used, which reduces the stress level of students by refusing to evaluate during the preparation of a written statement in favor of the final statement, as well as stimulating students' reflection to eliminate errors at all stages of work on a written text (Tarasov, 2015).

While working on the project, teachers and students use new media. The result of the implementation of the E-Mail project is the final product. The active use of modern mass media in the educational process has a number of advantages: the speed of information transfer, low financial costs, the availability of computer technologies and multimedia systems, and also contributes to the productive organization of the educational process for learning foreign languages in the form of an E-Mail project. The necessary basis for the successful implementation of the project is a carefully thought-out methodological structure and organization of E-Mail projects.

\section{MATERIALS AND METHODOLOGY OF THE STUDY}

The study included the following stages:

* the search-ascertaining was devoted to the study of the degree of elaboration of the problem based on the analysis of domestic and foreign scientific literature. A practice-oriented analysis of the experience of implementing E-Mail projects in the European educational space was carried out.

* the formative experiment was devoted to the development and implementation of their own international E-Mail projects; the development of a set of exercises focused on the development of writing and writing skills; identification of factors that have a positive and negative impact on the implementation of international E-Mail projects.

* control-generalizing assumed systematization and generalization of the obtained research results, quantitative and qualitative processing and analysis of the research results.

This scientific research is based on the use of a set of theoretical and empirical methods.

The components of the E-Mail project were developed, formed, and used in the process of its implementation at the following stages: the planning stage; the analytical stage; the stage of summarizing information; the stage of presenting the results of the project, evaluation, reflection (Hovhannisyan, 2015) (see Figure 1).

Having studied the practical experience of using E-Mail projects in foreign language classes in the European educational space, we can conclude that the views of domestic and foreign scientists on 
Figure 1. Stages of implementation of international E-Mail projects in the educational process (developed by the authors)

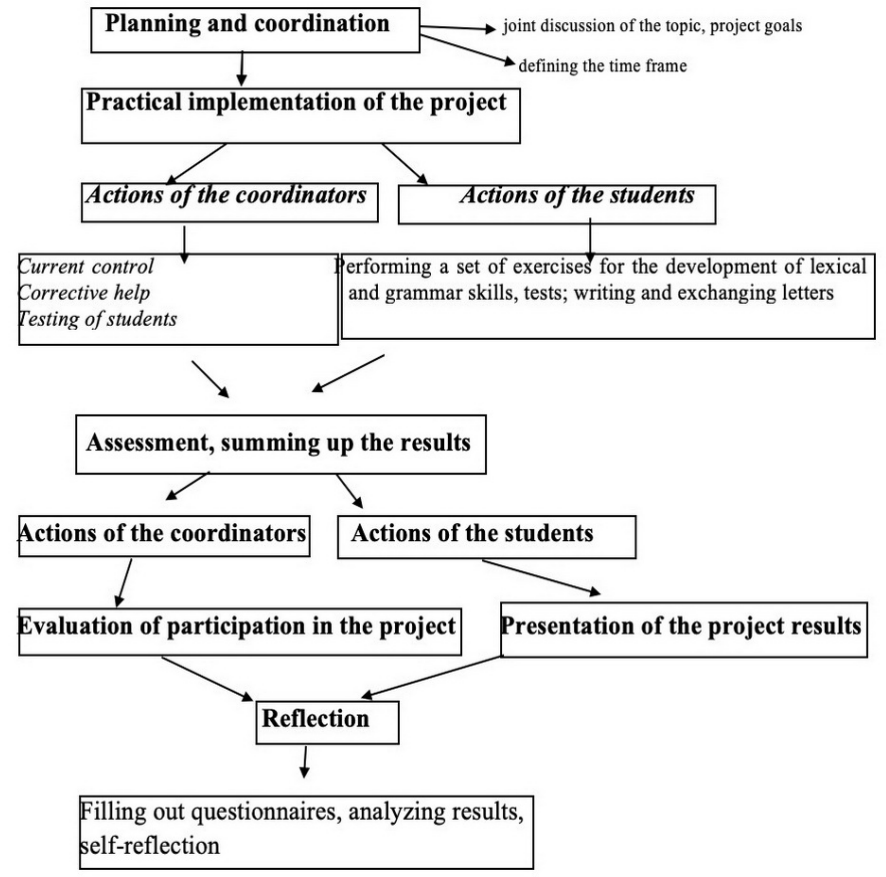

the methodological structure and organization of E-Mail projects are largely identical (Arranz, 2020; Hovhannisyan, 2015). Currently, the project method is undergoing its new development (Baibaturova, 2019; Lewis \& Peters, 2017; Pentyukhova, 2019; Samatkyzy, 2020).

\section{Planning and Coordination}

The first step to the successful implementation of an E-Mail project is a well-thought-out formulation of its purpose.

High motivation, involvement, interest, activity of students, coordination of the activities of all project participants, significantly affect the successful implementation of the project (Hattie \& Donoghue, 2016; Klein et al., 2014; Schiefele \& Schaffner, 2015).

At the stage of project approval, teachers and students determine the language in which communication will be carried out, the level of training of participants, their age, and the number of partners in the project.

\section{Realization}

At this stage, the practical implementation of the project is carried out, especially the teacher's corrective assistance is needed: the creation of various methodological developments on relevant issues, the development of an author's set of exercises that is focused on the formation, as well as the development, improvement of writing skills, fixing vocabulary on a certain topic. In each specific situation, the teacher must take into account the individual characteristics of the students, their level of training, the conditions for the implementation of the project (Kukaszewicz, 2021).

\section{Assessment, Summing Up, Reflection}

The reflection of the project is carried out by both students and teachers-coordinators. 
Project participants fill out a questionnaire, reflect on the results of the project; answers to questions encourage reflection and self-reflection. The accumulated positive and negative experience is relevant for the successful implementation of the following projects.

An important point is the teacher's control of the process of writing E-Mail letters by students, namely: the degree of text correction, the regularity of writing letters. Many students will have no uncertainty in the process of written communication if they know that their emails are written without a large number of grammatical, lexical, stylistic errors.

\section{Research Design}

At the first stage of the project implementation, the problem was posed, the topic of the E-Mail project was formulated, the project participants were determined.

Gymnasium am Tannenberg in Grevesmulen (Germany). The gymnasium's motto is "children need roots and wings" ("Kinder brauchen Wurzeln und Flügel"). Great importance is given to the study of foreign languages in the gymnasium, for example, English and Russian.

Anne-Frank Gymnasium (Anne-Frank-Oberschule) in Strausberg (Germany). The school is focused primarily on the professional training of students. Russian and English languages are studied at the gymnasium.

In order to identify the effectiveness of the implementation of E-Mail projects, the degree of satisfaction of students from participating in them, a survey of students was conducted at the final stage of the projects. The survey was conducted after the completion of each project. The respondents were students of the municipal budgetary educational institution of the city of Rostov-on-Don "School No. 60" (the Russian Federation). Since 2013, the school confirms the status of "School of Digital Technologies". The innovative activity of the school is focused on creating a modern and safe digital educational environment in the educational organization by 2024, ensuring high quality and accessibility of education of all types and levels. The number of respondents-students -17 people. A total of 5 surveys were conducted (see Table 1).

Table 1. Assessment questionnaire by students of their participation in the international E-mail project "My family and me"

\begin{tabular}{|l|l|}
\hline & Questions \\
\hline 1 & Do you find the implemented E-Mail project "My family and I" interesting? \\
\hline 2 & $\begin{array}{l}\text { Is participation in the preparation and implementation of an E-Mail project an important change in the } \\
\text { curriculum? }\end{array}$ \\
\hline 3 & Do you consider it important to exchange opinions and views with people from other countries? \\
\hline 4 & Does participation in an E-Mail project help you better master the training material? \\
\hline 5 & Do you want to work more often with email in the lesson? \\
\hline 6 & Did you get satisfaction from participating in the E-Mail project "My family and me"? \\
\hline 7 & Have you experienced difficulties in the correct use of vocabulary on the topic "My family and I"? \\
\hline 8 & Have you experienced difficulties in applying grammatical structures? \\
\hline 9 & Have you experienced any technical difficulties during the project implementation? \\
\hline
\end{tabular}

\section{Participants}

The respondents were 85 students of the municipal budget educational institution of the city of Rostov-on-don "School No 60 " at the age of 12 to 15 years who are learning German as a second foreign language and 25 of the coordinators of the international E-Mail-projects - teacher of German 
language at the age of 25 to 65 years, undergraduates and students of the Department of German Philology of the Institute of Philology, journalism and intercultural communication, Southern Federal University, aged 20 to 23 years.

\section{Survey}

To identify the students' assessment of their participation in international E-Mail projects, a continuous survey method was used. The classification of the questionnaire for students' assessment of their participation in international E-Mail projects was based on 3 signs: content, form and function. Based on the logic of the study, the number of questions was optimal, the answers to them provided completeness of information (Beller, 2016; Brosius, 2018; Döring \& Bortz, 2016; Marotzki \& Mieg, 2016; Mayring, 2016). The topic of the questionnaire is "My family and me", "My hobbies and interests", "Customs, traditions, holidays in Russia and Germany", "My city and my region", "My school, my favorite subject" (see Table 1).

\section{Testing}

In order to qualitatively assess the structure and effectively measure the level of lexical and grammatical skills of students, which are necessary to solve the set communicative tasks, we have developed tests:

- $\quad$ according to the form of the event - individual, written, blank;

- by content - educational;

- by goals - input / defining, forming;

* by function - controlling.

The complex of test tasks, which carries out the interrelation of the elements of the language material and the actions of operating with it in speech activity, made it possible to organize the gradual formation of language and speech grammatical skills.

\section{Data Analysis}

Processing and visualization of statistical data of the study was carried out using the tools of the MS Office 2019 package, in particular Microsoft Excel. A statistical analysis of the results of the implementation of international E-Mail projects was carried out. The results were combined using the method of automatic calculation of the reliability of differences between two dependent results according to the Student's t-criterion, a paired two-sample t-test for averages was used.

The maximum statistical error of the survey results is $\pm 0.6 \%$ for the sample of students studying German as a second foreign language.

\section{Ethical Restrictions}

All the survey data were obtained with the consent of the respondents, the parents of the students, the management of the educational organization where the E-mail projects were implemented.

\section{Research Limitations}

In order to determine how high school students evaluate their participation in international E-mail projects and how this participation affects motivation to learn German, an analysis of 85 questionnaires was conducted, which is a fairly reference sample. At the same time, it was necessary to take into account that in recent years the number of students studying German as a second foreign language has been decreasing.

As research limitations, the following are highlighted: 
* students' assessment of their participation in the implementation of E-mail projects; the impact of the implementation of E-mail projects on the motivation of students to learn German;

* 85 of the surveyed students, 25 of the surveyed project coordinators - a quantitative parameter;

* secondary school students learning German as a second foreign language; project coordinators - a qualitative indicator;

* international E-mail project - learning technology.

\section{RESULTS}

\section{The Results of the Questionnaire Assessment by Students of their Participation in International E-Mail Projects}

In the course of the study, all the necessary ethical restrictions were observed. The data obtained served as a basis for identifying the prospects for the use of international E-Mail projects in teaching foreign languages and formulating conclusions based on the results of the study. All the survey data were obtained with the consent of the respondents. Based on the results of the "Questionnaire of students' assessment of their participation in international E-Mail projects", we conclude that they have a positive attitude to participation in international E-Mail projects (91\%). A number of difficulties are noted: students experienced difficulties in the correct use of vocabulary on the relevant topic $(23.5 \%)$; in the application of grammatical structures (27\%); technical difficulties experienced (7\%).

The survey results confirmed our assumption about the positive attitude of students to participate in the international E-Mail project, students demonstrated a high degree of involvement in the learning process using e-mail. The results of the testing also determined the need for students to participate in international E-Mail projects for self-development as a subject of educational activity.

\section{Analysis of the Results of the Questionnaire Evaluation of International E-Mail Projects by the Coordinators}

The survey was conducted after the completion of each project. The students were teachers of German, undergraduates, students of the Department of German Philology of the Institute of Philology, Journalism and Interculturalommunication of the Southern Federal University. The number of project coordinator respondents is 25 people (see Table 2).

The analysis of the survey results confirms the interest of the project coordinators in the preparation and implementation of international E-Mail projects. The coordinators note the following positive points: the implementation of international E-Mail projects expands communication practice, organizes communication with a native speaker, allows you to go beyond the standard educational process. The negative factors of the respondents include a strictly regulated program, curriculum, insufficient amount of necessary educational materials, insufficient level of methodological training.

\section{Analysis of the Results of Testing the Level of Lexical and Grammatical Skills of Students}

The main forms of test tasks that were used during testing: tasks with a choice of an answer, tasks of an open form, tasks to establish the correct sequence, tasks to establish compliance.

Testing made it possible to assess the level of achievement of students as objectively as possible, to compare the results of students.

At the beginning of the implementation of each E-Mail project, an entrance test on the topic was conducted to establish the initial level of training. After the implementation of the project and the use of a set of exercises developed by us in the educational process, a control test was conducted. The method of calculating the reliability of the differences between the two dependent results according to the Student's t-criterion was used. The data presented in the tables (see Tables 3-7) confirm that the experimental $\mathrm{temf}^{3} \mathrm{t} \mathrm{kr}$. This indicates that the differences between arithmetic averages are considered 
Table 2. Analysis of the results of the questionnaire assessment by students of their participation in international E-Mail projects

\begin{tabular}{|c|c|c|c|c|}
\hline & Questions & Yes & No & $\begin{array}{l}\text { I find it } \\
\text { difficult to } \\
\text { answer }\end{array}$ \\
\hline 1 & Do you consider the implemented E-Mail project interesting? & $90 \%$ & $4 \%$ & $6 \%$ \\
\hline 2 & $\begin{array}{l}\text { Is participation in the preparation and implementation of an E-Mail } \\
\text { project an important change in the curriculum? }\end{array}$ & $89 \%$ & $5 \%$ & $6 \%$ \\
\hline 3 & $\begin{array}{l}\text { Do you consider it important to exchange opinions and views with } \\
\text { people from other countries? }\end{array}$ & $95 \%$ & $3.5 \%$ & $1.5 \%$ \\
\hline 4 & $\begin{array}{l}\text { Does participation in an E-Mail project help you better master the } \\
\text { training material? }\end{array}$ & $90 \%$ & $5 \%$ & $5 \%$ \\
\hline 5 & Do you want to work more often with email in the lesson? & $96 \%$ & $2 \%$ & $2 \%$ \\
\hline 6 & Did you get satisfaction from participating in the E-Mail project? & $91 \%$ & $5 \%$ & $4 \%$ \\
\hline 7 & $\begin{array}{l}\text { Have you experienced difficulties in the correct use of vocabulary on } \\
\text { the relevant topic? }\end{array}$ & $23.5 \%$ & $73 \%$ & $3.5 \%$ \\
\hline 8 & $\begin{array}{l}\text { Have you experienced difficulties in applying grammatical } \\
\text { structures? }\end{array}$ & $27 \%$ & $66 \%$ & $7 \%$ \\
\hline 9 & $\begin{array}{l}\text { Have you experienced any technical difficulties during the project } \\
\text { implementation process? }\end{array}$ & $7 \%$ & $86 \%$ & $7 \%$ \\
\hline
\end{tabular}

reliable. The empirical values obtained are in the zone of significance, p£0.05. Based on the application of the Student's t-test for connected samples, it can be concluded that as a result of the introduction of E-Mail projects into the educational process, there has been a significant increase in indicators, there is a positive trend in the level of training.

When automatically calculating the Student's t-test of the test results of students after the implementation of the E-Mail project "My Family and I", it was found that the empirical value of $t$ (16.6) is in the zone of significance at a critical value of 2.12, p£0.05 (see Table 3).

When automatically calculating the Student's t-test of the test results of students after the implementation of the E-Mail project "My interests and hobbies", it was revealed that the empirical value of $t(8.8)$ is in the zone of significance at a critical value of 2.12, p£0.05 (see Table 4).

With the automatic calculation of the Student's t-test of the test results of students after the implementation of the E-Mail project "My school, my favorite subject", it was determined that the empirical value of $t(12.5)$ is in the zone of significance at a critical value of 2.12, p£0.05 (see Table 5).

To automatically calculate student's t-test results of students after the implementation of the E-Mail of the project "My city and my region" established that the empirical value of $\mathrm{t}(9)$ is in the area of significance critical value of 2.12, p£0.05 (see Table 6).

To automatically calculate student's t-test results of students after the implementation of the E-Mail of the project "the Traditions, customs, holidays in Russia and Germany," it is revealed that the empirical value of $t(11.8)$ is in the area of significance critical value of 2.12, p£0.05 (see Table 7).

Control testing of students after the implementation of the E-Mail project "My family and I" revealed that the number of students with a high level of language proficiency increased by $17.6 \%$, with an average of $17.6 \%$ and with a low level of language proficiency decreased by $35.2 \%$ (see Figure 2). This is a significant indicator indicating the effectiveness of the developed set of exercises and the productive use of e-mail in the learning process.

Control testing of students after the implementation of the E-Mail project "My hobbies and interests" revealed that the number of students with a high level of language proficiency increased by $11.8 \%$, with an average of $9.8 \%$ and with a low level of language proficiency decreased by $23.6 \%$ (see Figure 3 ). 
Table 3. The final result of calculating the reliability of testing students. E-Mail-project "My family and I"

\begin{tabular}{|l|l|l|l|l|}
\hline No. & Sample 1 (V.1) & Sample 2 (V.2) & $\begin{array}{l}\text { Deviations (V.1 - } \\
\text { V.2) }\end{array}$ & $\begin{array}{l}\text { Squares of } \\
\text { deviations (V.1 - } \\
\text { V.2)2 }\end{array}$ \\
\hline 1 & 13 & 15 & -2 & 4 \\
\hline 2 & 13 & 15 & -2 & 4 \\
\hline 3 & 10 & 15 & -5 & 25 \\
\hline 4 & 8 & 14 & -6 & 36 \\
\hline 5 & 8 & 14 & -6 & 36 \\
\hline 6 & 7 & 12 & -5 & 25 \\
\hline 7 & 7 & 12 & -5 & 25 \\
\hline 8 & 7 & 11 & -4 & 16 \\
\hline 9 & 7 & 11 & -4 & 16 \\
\hline 10 & 6 & 10 & -4 & 16 \\
\hline 11 & 6 & 10 & -4 & 16 \\
\hline 12 & 5 & 10 & -5 & 25 \\
\hline 13 & 5 & 9 & -4 & 16 \\
\hline 14 & 4 & 9 & -5 & 25 \\
\hline 15 & 4 & 9 & -5 & 25 \\
\hline 16 & 3 & 8 & -5 & 25 \\
\hline 17 & 3 & 8 & -5 & 25 \\
\hline Amounts: & 116 & 192 & -76 & 360 \\
\hline & & & \\
\hline
\end{tabular}

Control testing of students after the implementation of the E-Mail project "My school, my favorite subject" revealed that the number of students with a high level of language proficiency increased by $17.6 \%$, with an average of $11.8 \%$ and with a low level of language proficiency decreased by $29.4 \%$ (see Figure 4 ).

Control testing of students after the implementation of the E-Mail project "My city and my region" revealed that the number of students with a high level of language proficiency increased by $23.6 \%$, with an average of $23.4 \%$ and with a low level of language proficiency decreased by $47 \%$ (see Figure 5).

Control testing of students after the implementation of the E-Mail project "Customs, traditions, holidays in Russia and Germany" revealed that the number of students with a high level of language proficiency increased by $23.4 \%$, with an average of $35.4 \%$ and with a low level of language proficiency decreased by $58.8 \%$ (see Figure 6).

The test results indicate a positive dynamics of the level of quality of training according to the methodology developed by us using the author's set of exercises for the development of grammatical and lexical skills. The level of students with a low level of language proficiency has significantly decreased. The most vividly positive dynamics is noticeable during the implementation of the E-Mail project "Customs, traditions, holidays in Russia and Germany". This is due to the relevance of the topic, the interest of students in the active use of authentic materials.

To identify the level of development of internal motivation of students' learning activities when learning German with the use of international E-Mail projects in the educational process, a modified Dubovitskaya methodology was used (Dubovitskaya, 2002). The methodology consists of 20 judgments and proposed answers. The answers in the form of pros and cons are recorded on a special form. The indicators of the questionnaire are calculated according to the key, where "Yes" means positive answers, and "No" means 
Table 4. The final result of calculating the reliability of testing students. E-Mail-project "My interests and hobbies"

\begin{tabular}{|c|c|c|c|c|}
\hline No. & Sample 1 (V.1) & Sample 2 (V.2) & $\begin{array}{l}\text { Deviations (V.1 - } \\
\text { V.2) }\end{array}$ & $\begin{array}{l}\text { Squares of } \\
\text { deviations (V.1 - } \\
\text { V.2)2 }\end{array}$ \\
\hline 1 & 13 & 15 & -2 & 4 \\
\hline 2 & 13 & 15 & -2 & 4 \\
\hline 3 & 13 & 14 & -1 & 1 \\
\hline 4 & 7 & 13 & -6 & 36 \\
\hline 5 & 7 & 13 & -6 & 36 \\
\hline 6 & 8 & 13 & -5 & 25 \\
\hline 7 & 8 & 13 & -5 & 25 \\
\hline 8 & 7 & 9 & -2 & 4 \\
\hline 9 & 7 & 11 & -4 & 16 \\
\hline 10 & 7 & 10 & -3 & 9 \\
\hline 11 & 6 & 10 & -4 & 16 \\
\hline 12 & 6 & 10 & -4 & 16 \\
\hline 13 & 5 & 9 & -4 & 16 \\
\hline 14 & 3 & 9 & -6 & 36 \\
\hline 15 & 3 & 5 & -2 & 4 \\
\hline 16 & 4 & 6 & -2 & 4 \\
\hline 17 & 4 & 6 & -2 & 4 \\
\hline Amounts: & 121 & 181 & -60 & 256 \\
\hline
\end{tabular}

negative ones. For each match with the key, 1 point is awarded. The higher the total score, the higher the indicator of internal motivation for studying the subject "German language". To determine the level of internal motivation, the following normative boundaries were used:

0 - 5 points - a low level of internal motivation

6 - 14 points - average level of internal motivation

15-20 points - a high level of internal motivation (see Figure 7).

When analyzing and comparing the data obtained by the indicator "High level" of internal motivation, it turns out that in the process of implementing international E-Mail projects, the number of students with this level of motivation increased from $27 \%$ to $34.5 \%$, an improvement is observed in $7.5 \%$. In students with an initially average level of internal motivation, improvement is observed in $6.5 \%$ of students. $15 \%$ of students with an initially low level of intrinsic motivation move on to higher levels of development of intrinsic motivation. The increase in the level of development of internal motivation of students indicates the effectiveness of the use of international E-Mail projects in the educational process.

\section{DISCUSSION}

Based on the analytical review of the literature on the research problem, generalization of pedagogical experience in the preparation and implementation of E-Mail projects in the European educational 
Table 5. The final result of calculating the reliability of testing students. E-Mail-project "My school, my favorite subject"

\begin{tabular}{|l|l|l|l|l|}
\hline No. & Sample 1 (V.1) & Sample 2 (V.2) & $\begin{array}{l}\text { Deviations (V.1 - } \\
\text { V.2) }\end{array}$ & $\begin{array}{l}\text { Squares of } \\
\text { deviations (V.1 - } \\
\text { V.2)2 }\end{array}$ \\
\hline 1 & 13 & 14 & -1 & 1 \\
\hline 2 & 13 & 14 & -1 & 1 \\
\hline 3 & 10 & 13 & -3 & 9 \\
\hline 4 & 8 & 13 & -5 & 25 \\
\hline 5 & 9 & 13 & -4 & 16 \\
\hline 6 & 7 & 11 & -4 & 16 \\
\hline 7 & 7 & 11 & -4 & 16 \\
\hline 8 & 7 & 10 & -3 & 9 \\
\hline 9 & 7 & 10 & -3 & 9 \\
\hline 10 & 7 & 10 & -3 & 9 \\
\hline 11 & 5 & 9 & -4 & 16 \\
\hline 12 & 6 & 9 & -3 & 9 \\
\hline 13 & 5 & 8 & -3 & 9 \\
\hline 14 & 5 & 8 & -3 & 9 \\
\hline 15 & 4 & 8 & -4 & 16 \\
\hline 16 & 3 & 5 & -2 & 4 \\
\hline 17 & 2 & 5 & -3 & 9 \\
\hline Amounts: & 118 & 171 & -53 & 183 \\
\hline & & & \\
\hline
\end{tabular}

space, we have developed a number of international E-Mail projects. We not only proved the relevance of the development of E-Mail projects, but also analyzed our author's approach to the preparation and implementation of international projects. This approach was developed on the basis of the synthesis of conceptual provisions of competence, system, activity, dialog approaches, which eliminated fragmentation in solving the research problem, allowed identifying and applying methodological goals adequate to the nature of the phenomenon under study. Let's take a closer look at the stages of the implementation of the international E-Mail project "Brieffreunde".

A distinctive feature of the Brieffreunde E-Mail project implemented by us was its bilingual orientation. The languages of electronic communication were Russian and German. It is interesting that the students of the German gymnasium used Russian as the language of correspondence, and Russian schoolchildren used German. Knowledge of German and Russian languages was sufficient to carry out written communication and solve the set communicative tasks (Shapovalova et al., 2019).

During the implementation of our project, this stage was productive with minimal time spent on solving organizational issues, as contact was established very quickly between the teachers-project coordinators. The coordinator from the Russian side worked as a language assistant during her internship at the Gymnasium am Tannenberg in Grevesmulen (Germany). The project coordinators kept in touch constantly. According to the "International Computer and Information Literacy Study" (ICILS 2018), only about a quarter of German teachers receive knowledge, skills, and skills of using ICT in the educational process during their studies at the university. Russian teachers are also experiencing similar problems. These gaps can be filled, first of all, in advanced training courses. 
Table 6. The final result of calculating the reliability of testing students. E-Mail-project "My city and my region"

\begin{tabular}{|l|l|l|l|l|}
\hline No. & Sample 1 (V.1) & Sample 2 (V.2) & $\begin{array}{l}\text { Deviations (V.1 - } \\
\text { V.2) }\end{array}$ & $\begin{array}{l}\text { Squares of } \\
\text { deviations (V.1 - } \\
\text { V.2)2 }\end{array}$ \\
\hline 1 & 13 & 15 & -2 & 4 \\
\hline 2 & 12 & 14 & -2 & 4 \\
\hline 3 & 11 & 14 & -3 & 9 \\
\hline 4 & 10 & 13 & -3 & 9 \\
\hline 5 & 10 & 13 & -3 & 9 \\
\hline 6 & 6 & 12 & -6 & 36 \\
\hline 7 & 6 & 11 & -5 & 25 \\
\hline 8 & 6 & 11 & -5 & 25 \\
\hline 9 & 6 & 12 & -6 & 36 \\
\hline 10 & 5 & 11 & -6 & 36 \\
\hline 11 & 5 & 10 & -5 & 25 \\
\hline 12 & 5 & 9 & -4 & 16 \\
\hline 13 & 4 & 6 & -2 & 4 \\
\hline 14 & 4 & 6 & -2 & 4 \\
\hline 15 & 3 & 5 & -2 & 4 \\
\hline 16 & 3 & 5 & -2 & 4 \\
\hline 17 & 2 & 4 & -2 & 4 \\
\hline Amounts: & 111 & 171 & -60 & 254 \\
\hline & & & \\
\hline
\end{tabular}

The decision to implement the project was supported by the school management. Such support has a positive impact on the motivation of teachers to organize and conduct projects (Ulmer-Leahey, 2019).

At the second stage, a detailed development of the project implementation process was carried out, taking into account the peculiarities of the educational process in the MBOU "School No. 60" in Rostov-on-Don and the gymnasium am Tannenberg in Grevesmulen. Working groups were created. Group work contributes to success in communication, it helps individual students overcome their language insecurity. As the implementation of the E-Mail project has shown, the productive work of groups contributes to a higher quality of training (see Figures 2-6). Organizational difficulties related to the difference in curricula, programs, schedules were resolved in a working manner. Students could carry out written communication at a convenient time for everyone.

At the third stage of the practical implementation of the project, it was planned to write letters on pre-agreed topics. We have developed an author's set of exercises aimed at developing students' writing skills. When performing this set of exercises, students experienced difficulties in using vocabulary on the topic of the project and the corresponding grammatical structures. 
Table 7. The final result of calculating the reliability of testing students. E-Mail-project "Customs, traditions, holidays in Russia and Germany"

\begin{tabular}{|c|c|c|c|c|}
\hline No. & Sample 1 (V.1) & Sample 2 (V.2) & $\begin{array}{l}\text { Deviations (V.1 - } \\
\text { V.2) }\end{array}$ & $\begin{array}{l}\text { Squares of } \\
\text { deviations (V.1 - } \\
\text { V.2)2 }\end{array}$ \\
\hline 1 & 13 & 14 & -1 & 1 \\
\hline 2 & 13 & 14 & -1 & 1 \\
\hline 3 & 11 & 14 & -3 & 9 \\
\hline 4 & 10 & 13 & -3 & 9 \\
\hline 5 & 9 & 13 & -4 & 16 \\
\hline 6 & 6 & 9 & -3 & 9 \\
\hline 7 & 6 & 9 & -3 & 9 \\
\hline 8 & 6 & 9 & -3 & 9 \\
\hline 9 & 6 & 8 & -2 & 4 \\
\hline 10 & 6 & 8 & -2 & 4 \\
\hline 11 & 6 & 8 & -2 & 4 \\
\hline 12 & 5 & 8 & -3 & 9 \\
\hline 13 & 4 & 7 & -3 & 9 \\
\hline 14 & 4 & 7 & -3 & 9 \\
\hline 15 & 4 & 7 & -3 & 9 \\
\hline 16 & 3 & 5 & -2 & 4 \\
\hline 17 & 3 & 4 & -1 & 1 \\
\hline Amounts: & 115 & 157 & -42 & 116 \\
\hline
\end{tabular}

Figure 2. E-Mail project "My family and I"

«My family and |»

口Highlevel aMedium level alowlevel

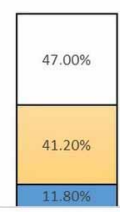

Input test

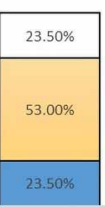

Forming test

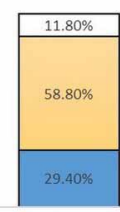

Controlling test 
International Journal of Web-Based Learning and Teaching Technologies Volume 17 • Issue 1

Figure 3. E-Mail project "My hobbies and interests"

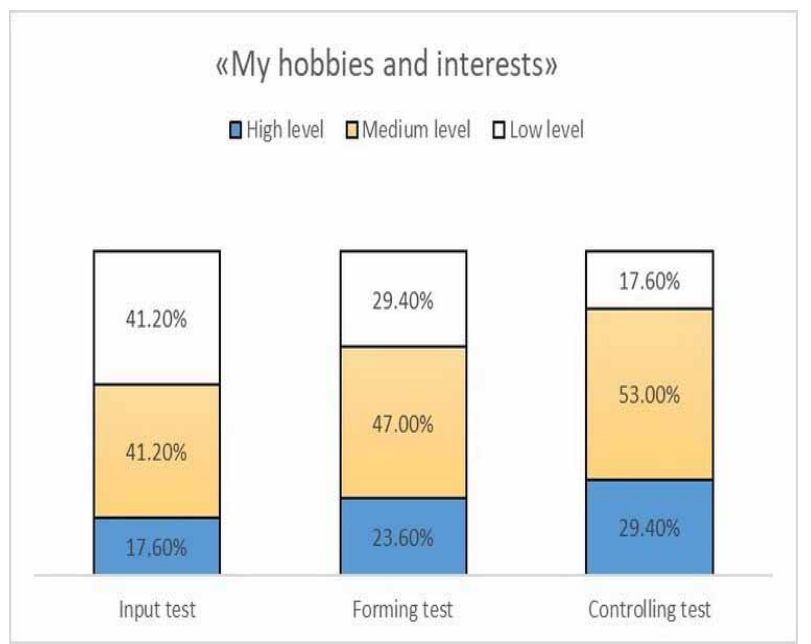

Figure 4. E-Mail project "My school, my favorite subject"

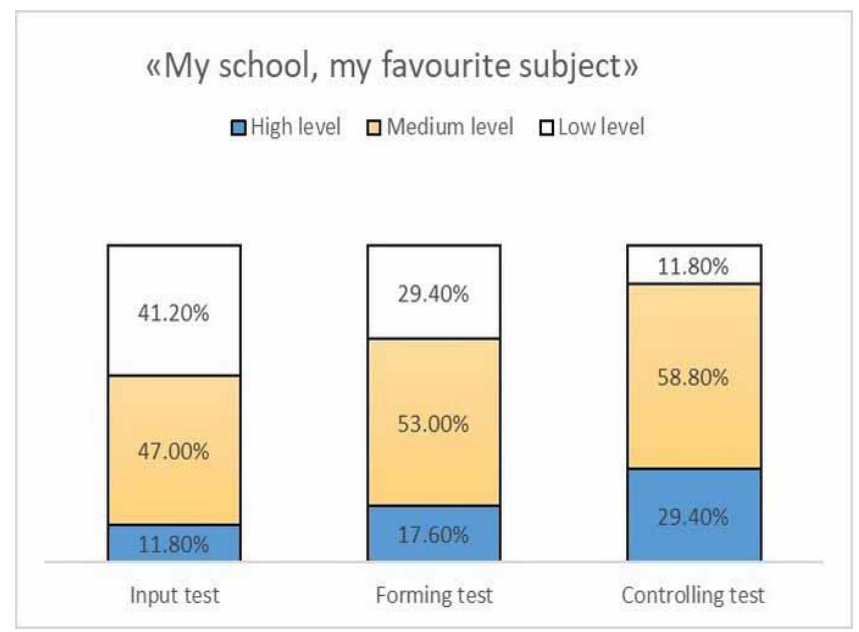

Figure 5. E-Mail project "My city and my region"

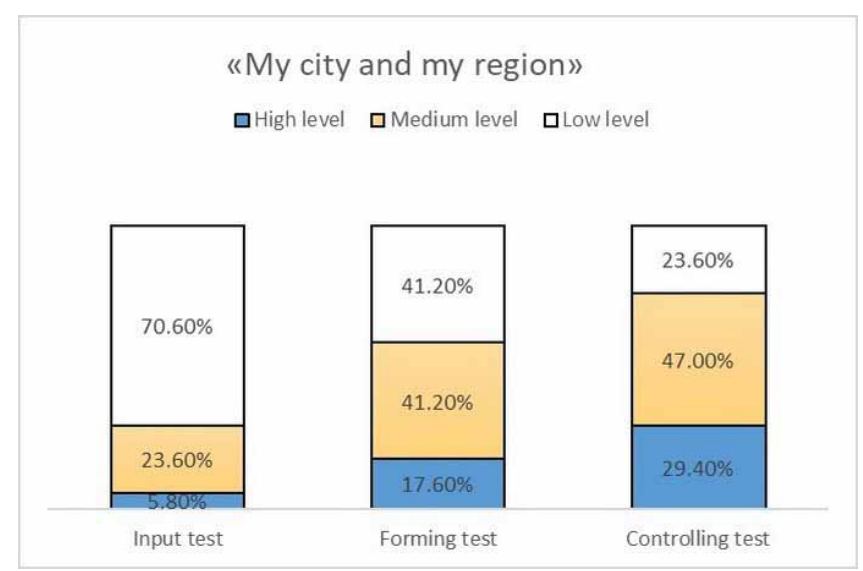


Figure 6. E-Mail project "Customs, traditions, holidays in Russia and Germany"

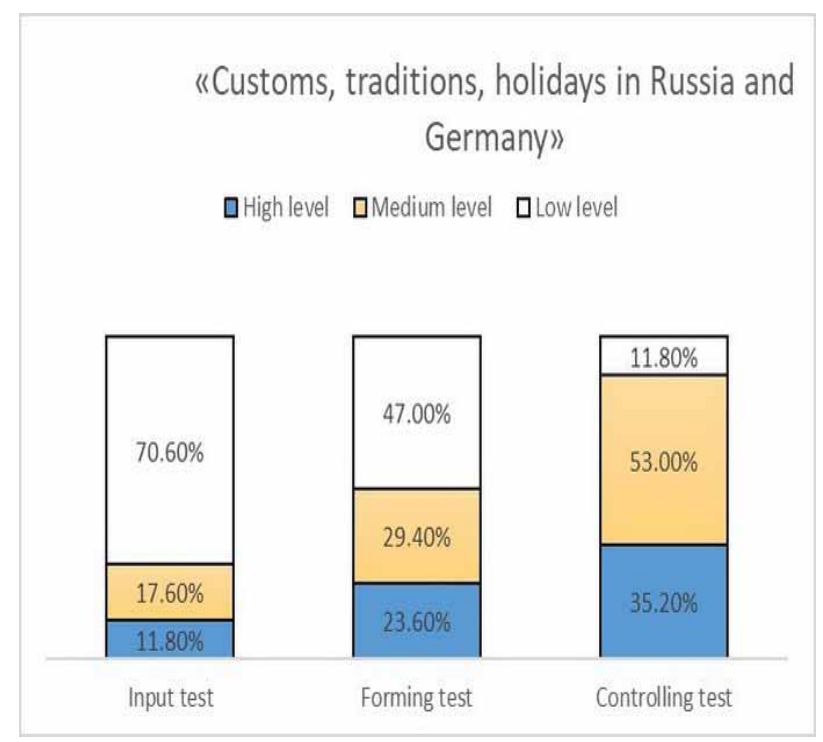

Figure 7. Development of self-motivation for student s learning activity in the prozess of implementing international E-Mail-Projects

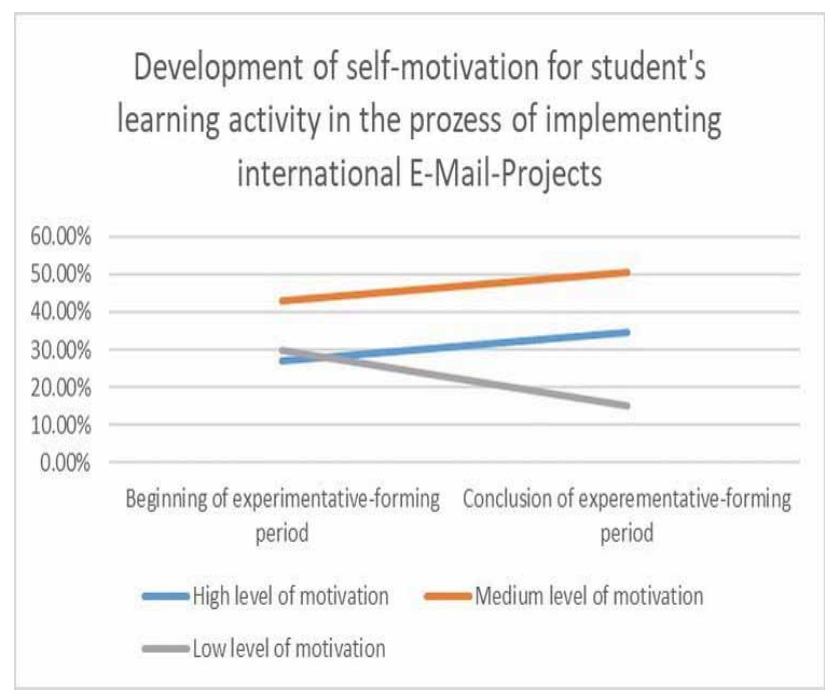

Teaching techniques and teaching techniques were implemented in a set of exercises. The essence of the set of exercises developed by us is as follows. At the first stage of skill formation, an indicative basis is created for performing further exercises at subsequent stages of skill formation. At the training stage, students perform exercises that activate their mental activity, perform actions in variable speech situations, which leads to the automation of speech operations and the formation of plastic, labile properties of the skill, its flexibility. The implementation by students of the exercises developed by us contributes not only to the assimilation of knowledge, the formation of skills, but also stimulates mental activity: intellectual, emotional, volitional, thus creating prerequisites for the intellectual development of students. An important positive factor for the successful implementation of international E-Mail projects using the set of exercises developed by us is the creation of a situation 
of success and personal growth for each student. At the same time, we are based on the humanistic position that success in teaching has a significant and sometimes decisive impact on the search activity of students. We bring to the fore the tasks of developing students' stable motivation for learning, which is an important moment of stimulating thinking, interest in learning, learning independence and the skills necessary for it, related to the awareness of the learning task with the search for its solution, and for this with the performance of various mental operations, with the organization of control over their actions and their assessment.

At the fourth stage, the results of the project were summed up, the results of the project were evaluated, the work of each student and the entire group as a whole was evaluated. E-mail projects in foreign language lessons complement the educational material, make possible real communication with partners from other countries, improve the communicative competencies of students, create opportunities for interactive interaction of project participants. In today's complex epidemiological conditions, e-mail is an actual learning technology that creates conditions for real communication (Forsa, 2020; Wildemann \& Hosenfeld, 2020).

The conducted project allows us to conclude that the intercultural communication of students in writing within the framework of the educational process represents the most relevant potential for integrating e-mail into the process of learning a foreign language. The received E-mail letters are authentic materials and can be productively used in foreign language lessons. The authenticity of educational materials is the leading factor for the formation of regional and intercultural components of foreign language lessons.

\section{CONCLUSION}

The realization of the opportunities provided by the use of modern ICT in the process of teaching foreign languages significantly expands the range of types of educational activity, creates conditions for the development of effective forms, methods, and technologies of teaching. The study of the possibilities of using international E-Mail projects in the process of teaching foreign languages has demonstrated that the use of e-mail technologies expands the creative abilities of the teacher, improves the academic performance and motivation of students, promotes the development of written communication skills.

The implementation of the E-Mail project contributes primarily to the development of the ability of students to know reality, to orient themselves in this reality. Participation in E-Mail projects contributes to the formation and development of practical intelligence among students.

The study analyzes the results of the use of E-Mail projects in the process of teaching a foreign language. The results make it possible to conclude that intercultural communication via e-mail within the framework of the educational process creates the possibility of authentic communication, authentic interaction, which is extremely important for successful intercultural communication. E-mail projects have great potential, promote intercultural communication. The use of E-mail projects in the educational process, especially in the context of a pandemic, when the possibilities of real communication are significantly limited, seems to us relevant and productive.

The practical significance of the research lies in the fact that educational and methodological materials developed in the process of implementing international E-Mail projects are used in the educational process in educational institutions where E-Mail projects were implemented, are of practical interest to teachers-practitioners of other educational institutions, integrated into the process of training future teachers of a foreign language of the Institute of Philology, Journalism and Intercultural Communication of the Southern Federal University.

The development of international E-Mail projects on an interdisciplinary basis seems promising. In the process of implementing future E-Mail projects together with teachers of literature, history, geography, music "Our outstanding countrymen - Sholokhov M.A., Chekhov A. P.", "The city by the sea - the history of the founding of the city of Taganrog by Peter I, the city of Taganrog - the 
hometown of A.P. Chekhov", it is planned to use modern IT technologies: videoconferences and virtual excursions.

\section{DECLARATIONS}

Funding. The publication was made within the framework of the publication activity support program of the Southern Federal University.

Conflicts of interest. Authors declare that they have no any financial interest or benefit that has arisen from the direct applications of research.

Availability of data and material. Data will be available on request.

Code availability. Not applicable.

Authors' contributions. LS conceived and designed the analysis; NK collected the data; EP contributed data or analysis tools; YG performed the analysis; LS, NK, EP and YG wrote the paper. All authors read and approved the final manuscript.

Acknowledgments. Not applicable.

Ethics approval. All procedures performed in studies involving human participants were in accordance with the ethical standards of the institutional and/or national research committee and with the 1964 Helsinki declaration and its later amendments or comparable ethical standards.

Consent to participate. All the survey data were obtained with the consent of the respondents, the parents of the students, the management of the educational organization where the E-mail projects were implemented.

Consent for publication. Not applicable. 


\section{REFERENCES}

Afanasyeva, T. Y. (2018). The potential of E-mail projects in the development of sociolinguistic competence of students of non-linguistic universities. In N. E. Chernyavskaya \& M. S. Bykanova (Eds.), Actual problems of methods of teaching philological disciplines in higher and secondary specialized educational institutions. Collection of materials of the VIII All-Russian scientific and practical conference (pp. 57-60). Academic Press.

Angelova, M. N., \& Dadoyan, Y. S. (2015). Distance learning of foreign languages through computer telecommunications networks Internet. Innovative Science, 2(5), 155-159.

Arranz, B. (2020). E-Tandem: An e-mail project in secondary education. Valladolid.

Baibaturova, L. A. (2019). E-Mail projects in teaching foreign languages. Technologies of Education, 2(4), $323-325$.

Balkan, F. (2020). The use of new media in Daf teaching. A contrastive and semiotic analysis of the use of multimedia tools in the context of new learning - new action. Inaugural Dissertation.

Beller, S. (2016). Empirical research learning. Concept, methods, case studies, tips (3rd ed.). Hogrefe.

Berndt, M. S. (2020). Digitales Lernen senkt die Angst vor Fremdsprachen. Die Presse. https://www.diepresse. com/5904042/digitales-lernen-senkt-die-angst-vor-fremdsprachen

Brosius, F. (2018). SPSS. Comprehensive manual on statistics and data analysis (8th ed.). Verlag.

Chen, J., Wang, M., Kirschner, P. A., \& Tsai, C.-C. (2018). The role of collaboration, computer use, learning environments, and supporting strategies in CSCL: A meta-analysis. Review of Educational Research, 88(6), 799-843. doi:10.3102/0034654318791584

Claussen, T., \& Pavlovska-Balcerska, A. (2018). A German-Polish E-mail-Tandem with advanced learners of German as a foreign language and future teachers: An example for an international teaching cooperation. InfoDaF, 45(5), 655-671.

Döring, N., \& Bortz, J. (2016). Research methods and evaluation in the social and human sciences (5th ed.). Springer.

Dubovitskaya, T. D. (2002). Methodology for diagnosing the orientation of educational motivation. Psychological Science and Education, 2, 42-45.

Forsa. (2020). The German school barometer special corona crisis: Results of a survey of teachers in general education schools. In R. Bosch (Ed.), Forsa Politik-und Sozialforschung GmbH. Forsa.

Gorovenko, L. A. (2018). Organization of distance learning using Internet technologies. In L. A. Gorovenko \& G. A. Aleksanyan (Eds.), Bulletin of the Adygea State University. The series "Natural-mathematical and technical sciences" (No. 4., pp. 220-225). Publishing house of ASU.

Hattie, J., \& Donoghue, G. (2016). Learning strategies: A synthesis and conceptual model. Science of Learning, 1(1), 16013. doi:10.1038/npjscilearn.2016.13 PMID:30792898

Horno, U. (2018). Cultural studies as a motivating factor in DaF classes for Spanish students at the official language school (EOI) in Salamanca. Universidad De Salamanca.

Hovhannisyan, L. A. (2015). The use of the project method in the educational process. In L. A. Hovhannisyan \& M. A. Hakobyan (Eds.), Tavrichesky scientific observer. Pedagogy series (No. 2, pp. 101-104). Academic Press.

Ilic, S. (2018). Project teaching and its application in the DaF. Academic Press.

Jeong, H., Hmelo-Silver, C. E., \& Jo, K. (2019). Ten years of computer-supported collaborative learning: A meta-analysis of CSCL in STEM education during 2005-2014. Educational Research Review, 28, 100284. doi:10.1016/j.edurev.2019.100284

Klein, P. D., Boscolo, P., Kirkpatrick, L. C., \& Gelati, C. (2014). Writing as a learning activity. Brill. 
Klieme, E. (2020). Good teaching - even and especially under restrictions of the pandemic? In D. Fickermann \& B. Edelstein (Eds.), "Slowly I miss school...". School during and after the Corona pandemic (pp. 117-135). Waxmann.

Köller, O., Fleckenstein, J., Guill, K., \& Meyer, J. (2020). Pedagogical and didactic requirements for domestic task processing. In D. Fickermann \& B. Edelstein (Eds.), "Slowly I miss school ...". School during and after the Corona pandemic (pp. 163-174). Waxmann.

Kyzy, A. I., Mukhametzyanova, F. G., \& Khalilullina, A. R. (2018). Research of the role of information technologies in teaching foreign languages. Kazan Bulletin of Young scientists Pedagogical sciences. Teacher of the XXI century, 2(3.6), 128-134.

Lewis, T., \& Peters, H. (2017). Learning languages in tandem: Principles \& competence acquisition. In Learning processes in tandem - enabling, accompanying, researching. Contributions to the international Scientific Tandem Conference in Greifswald 2017 (pp. 11-32). Academic Press.

Łukaszewicz, A. (2021). The cookbook for e-mail projects in German lessons. Goethe. https://www.goethe.de/ ins/pl/lp/prj/bld/dnl/deindex.htm

Makkoveeva, Y. A. (2016). Didactic possibilities of electronic messages in teaching written speech. New Word in Science and Practice: Hypotheses and Approbation of Research Results, 26, 68-71.

Mann, C., \& Burgemeister, M. (2018). E-mail project with an American school as AG. SEMIK - Projekt MedienBausteine Sachsen-Anhalt.

Marotzki, M., \& Mieg, H. A. (2016). Professional development manual. Julius Klinkhardt.

Mayring, P. (2016). Introduction to qualitative social research. An introduction to qualitative thinking (6th ed.). Belletz.

Pavlovska, A. (2014a). How should my tandem partner correct my mistakes? About one of the important dilemmas in eTandem using the example of German and Polish students. In Z. Weigt, D. Kaczmarek, J. Makowski, \& M. Michoń (Eds.), Didactic and linguistic implications of intercultural communication. Fields of language - fields of research (pp. 55-68). Wydawnictwo Uniwersytetu Łódzkiego.

Pavlovska, A. (2014b). Writing in "different garb"? The role of e-mail in everyday (school)life. Germanica Wratislaviensia, 139, 393-406.

Pentyukhova, M. A. (2019). International E-Mail projects for preparation for the Unified State Exam in a foreign language. In Problems of linguistics and linguodidactics. Collection of student creative works and scientific articles (pp. 27-29). Glazov.

Rudeau, D. (2021). To what extent are textbooks an adequate enrichment for modern language teaching? Language teaching without a textbook. Arts \& Sciences Electronic Theses and Dissertations. Washington University. https:// openscholarship.wustl.edu/art_sci_etds/2285

Ruthner, A. R. (2019). On language and culture mediation through intercultural encounters using face - toface contacts, ethnography, tandem learning, network - and media - supported teaching and learning processes and culture-sensitizing Methods. Professional Communication and Translation Studies, 12, 149-157.

Samatkyzy, M. (2020). E-Mail Projects as an innovative method in teaching English. Actual Scientific Research in the Modern World, 9(65.4), 9-12.

Schiefele, U., \& Schaffner, E. (2015). Motivation. Educational psychology. Springer.

Shapovalova, L. I., Khoruzhenko, N. A., \& Zakharova, L. G. (2019). Implementation of the international E-mail project Brieffreunde. The World of University Science: Culture, Education, 6, 19-26.

Shodmonov, D. A. (2020). Evaluation of modern education systems: Cloud, mobile and remote technologies. Young Scientist, 19(309), 520-524.

Tarasov, A. A. (2015). Theory and technology of teaching foreign-language productive written speech in primary school (on the example of personal writing). Online Journal Science Studies, 7(4), 1-18. 
Ulmer-Leahey, C. (2019). School and world-how can project-oriented school lessons resemble and function? Monograph.

Wildemann, A., \& Hosenfeld, I. (2020). Nationwide parent survey on homeschooling during the Covid-19 pandemic. Findings on the implementation of homeschooling in Germany. Institute for Education in Childhood and Adolescence University of Koblenz-Landau, Center for Empirical Pedagogical Research (ZEPF).

Zaliznyak, A. A., \& Mikaelyan, I. (2006). E-mail correspondence as a linguistic object. In Computational Linguistics and Intelligent Technologies: Proceedings of the International Conference (pp. 157-162). Dialogue. https://www.dialog-21.ru/digests/dialog2006/materials/html/Zalizniak.htm

Larisa Shapovalova has a Doctorate of Pedagogical Sciences degree. She is a Professor of the Southern Federal University, Rostov on Don, Russian Federation.

Natalija Koljada has a PhD of Philosophical Sciences degree. She is an Associate Professor of the Southern Federal University, Rostov on Don, Russian Federation.

Ekaterina Petrova has a PhD of Philological Sciences degree. She is an Associate Professor of the Southern Federal University, Rostov on Don, Russian Federation.

Yulia Gorpennikova is a Senior Lecturer of the Southern Federal University, Rostov on Don, Russian Federation. 